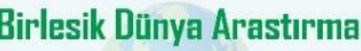 BD.CENTER \\ Innovasyon ve Yayınellik Merkezi \\ Proceedings on Humanities \\ and Social Sciences}

New Trends and Issues

Volume 8, Issue 3 (2021) 143-158

www.prosoc.eu

Selected Paper of 13th World Conference on Educational Sciences (WCES-2021) 04-06 February 2021, University of Cadi Ayyad,

Marrakech, Morocco

\title{
Development of information culture of rural school children in the Republic of Kazakhstan
}

Salima Seitenova*, Baishev University, Zhubanov Brothers St 302A, Aktobe, Kazakhstan

Samanta Iztleuova, Baishev University, Zhubanov Brothers St 302A, Aktobe, Kazakhstan

Aliya Imagambetova, Baishev University, Zhubanov Brothers St 302A, Aktobe, Kazakhstan

\section{Suggested Citation:}

Seitenova, S., Iztleuova, S., \& Imagambetova, A. (2021). Development of information culture of rural school children in the Republic of Kazakhstan. New Trends and Issues Proceedings on Humanities and Social Sciences. 8(3), pp 143-158. https://doi.org/10.18844/prosoc.v8i3.6406

Received from February 18, 2021; revised from April 13, 2021; accepted from August 29, 2021.

Selection and peer review under responsibility of Assoc. Prof. Dr. Jesus Garcia Laborda, University of Alcala, Spain. ${ }^{\circ}$ 2021, Birlesik Dunya Yenilik Arastirma ve Yayincilik Merkezi. All rights reserved.

\begin{abstract}
The explosive flow of digital technologies, the growth of social networks, cloud services, the global fascination with mass open online courses, unlimited access to growing Internet resources, the shift of progressive humanities towards the production of digital tools have led to a serious problem in Kazakhstan. Purpose of the article is to study the possibilities of digitalization of rural education in the Republic of Kazakhstan for the development of information culture of schoolchildren. The methods of scientific research are the conceptual foundations of scientific knowledge (methods of developing ideas: targeted discussions; "brainstorming"; inventory of "weak points"; methods of creative problem solving; heuristic method; method of cost analysis, and others). The final result of the study is an analytical and structured system that reveals the possibilities of digitalization of rural education in the Republic of Kazakhstan for the development of information culture of schoolchildren.
\end{abstract}

Keywords: digitalization of education, rural school, information culture, system moodle

* ADDRESS FOR CORRESPONDENCE: Samanta Iztleuova, Baishev University, Zhubanov Brothers St 302A, Aktobe, Kazakhstan.

E-mail address: samanta.iztleuova@mail.ru 


\section{Introduction}

Geographical and natural conditions, cyber socialisation of society and the viral pandemic, have focused on the problem of digitalisation of rural education for Kazakhstan. This study involves studying the possibilities of digital resources in teaching rural schoolchildren: mobile application technologies, VR technologies, moodle.org system, electronic student notebooks and learning environments. These resources teach rural schoolchildren to operate with educational information, which contributes to the development of the information culture of schoolchildren. Ignatova (2017) emphasises that the information society changes the ontology of education, since the space (topos) and the time of the life-world (temporality) of a person change. In the information society, changes are observed at the level of the deep basis of time, manifested in the de-synchronisation of processes in real and virtual reality (Ignatova, 2017).

The prerequisites for the study were the following trends:

- Fuzzy, blurred and unregulated forms of digital education (distance, open and virtual) in the system of general secondary education;

- Change in spatial and temporal relationships between all participants in the pedagogical process;

- The positive aspects of digital education - no division into rural and urban students;

- Competition between educational communities; their level of professional competence / incompetence;

- Weak material and technical bases of rural schools and economic opportunities for rural families;

- The level of digital competencies of teachers and students;

- Force majeure, unforeseen circumstances at the level of a settlement, country and world.

- Cyber resilience to the digital world.

The purpose of the article is to study the possibilities of digitalisation of rural education in the Republic of Kazakhstan for the development of information culture of schoolchildren.

The scientific research methods are as follows:

- Conceptual foundations of scientific knowledge (methods of generating ideas: targeted discussions, 'brainstorming', inventory of 'weak points', methods of creative problem-solving, heuristic method, method of value analysis and others);

- Analysis of psychological, pedagogical, socio-economic and technical literature on the research problem; comparative and systemic-structural analysis;

- The critical path method, questionnaires, expert assessments and inventive activity analysis.

The theoretical basis of the scientific project was the work of domestic scientists in the following areas: the strategic direction of modernisation of pedagogical education in the conditions of innovative development by Abylkassymova (2015), Shkutin (2002) and Seitaliyev (2010); pedagogical technologies by Galiev (2011) and Karaev (2013); information educational technologies by Kusayynov and Bulatbaeva (2009) and Nurgalieva et al. (2015); and modernisation of a small school by Kontaev (2004) and Adilgazinov and Otcheskaya (2005).

\section{Results}

The issue of identifying opportunities for digitalisation of rural education in Kazakhstan deserves special attention for conducting scientific research, since in Kazakhstan the percentage of the rural population is 7,649.1 thousand people (42\%). The explosive flow of digital technologies, the growth of social networks, cloud services, the global passion for mass open online courses, unlimited access to growing Internet resources and the movement of progressive humanitarian science towards the production of digital tools led to a serious problem - the level of formed information culture of rural school students to accept such a digital wave. 
So, according to the website https://cabar.asia, as of 20 June 2020, 7,391 schools are covered in secondary education in Kazakhstan, these are about 3.3 million students, about 347 thousand teachers, 2,833 small schools and about 195.8 thousand rural students (Saurambaeva, 2020). Since 2013, the e-government has been launched in Kazakhstan; the e-learning programme has been introduced to implement the concept of e-learning in schools in the country. However, the coronavirus pandemic showed an insufficient level of readiness of Kazakh education to force majeure conditions. If, in urban schools, teachers, students and parents are provided with the necessary conditions and have shown quick adaptation to remote classes, then statistics are silent about the educational process in a rural school. As you know, during the introduction of distance learning in Kazakhstan, Facebook was full of illustrations and brief information that rural school students have to climb to the top of a mountain or to the roof of the house in order to 'catch' a wave of the Internet and other similar problems.

\subsection{Overview of previous world studies}

Khan Academy (https://ru.khanacademy.org) - a world-famous virtual school - has instantly adapted and been rebuilt to the changes taking place in the world. Given the coronavirus pandemic, the content of information resources is directed towards the student, the teacher and the parent.

Coursera (https://ru.coursera.org) - a digital educational platform - allows one to listen to lectures by the world's leading scientists. Currently, its capabilities cover not only advanced training courses, but also professional retraining and project programmes from leading universities in the world.

Massive open online courses (www.moos-ivp.org) or a massive open online course allows one to study remotely. Initially, MOOC courses were organised by European educational institutions to educate students who are unable, primarily financially, to study directly at the university. Currently, in addition to students, the courses are attended by specialists from various professional fields and organisations who want to expand and deepen their knowledge in various topics and areas. In Estonia, back in 1996, the Tiger Leap Programme was launched, which was based on three main directions: providing all schools with computers and the Internet, basic teacher training and conducting e-courses in Estonian for general education institutions. As a result, in 2000, all schools in Estonia were equipped with computers, and by 2001 they had Internet access (Estonia, 2000). In fact, the widespread use of the online platform in Estonian schools has been a key factor in enabling the country to ensure a smooth, 'painless' transition to distance learning during the global lockdown. It should be taken into account that not only the coronavirus can transform our usual reality. For example, in Kazakhstan, there are severe winters inherent in the northern regions of the country, which does not allow schoolchildren to attend classes at a certain period of time every day, and this also negatively affects the quality of education in general.

In the Russian business trend SKOLKOVO, the educational development centre of the SKOLKOVO Business School translated the 2017 report for the Russian-speaking audience and made an overview of ten key trends in transformations in the educational sphere (trends.skolkovo.ru, 2017), which are as follows:

1. The introduction of progressive teaching methods requires a cultural transformation.

2. Teaching real practical skills will improve professional qualifications.

3. Collaboration is a key factor in the dissemination of effective solutions as its ability to cooperate in the global market.

4. Although technology and online learning materials are widespread, they are still not available to everyone.

5. Processes should be established to assess skills at the individual level.

6. Being able to use technology is not enough to feel free in the digital world.

7. The effectiveness of online learning, as well as mobile and blended learning, is beyond question.

8. Educational ecosystems must be flexible enough to accommodate entirely new learning methods. 
9. Higher education is an excellent environment for developing more intuitive computers. 10. Lifelong learning is the foundation of higher education.

According to the results of the class central study in 2016, educational platforms were represented by more than 700 universities, 6,850 courses and 58 million students were trained on them. According to the college data website, the average university has between 5,000 and $15,000-20,000$ students; the Coursera educational platform has 23 million students; EdX 10 million; XuetangX (the first nonEnglish language platform to be included in the top five leading MEPs in the world) has 6 million; FutureLearn has 5.3 million and Udacity has 4 million.

The study and analysis of scientific and theoretical literature identified the essential concepts of 'information culture', 'rural school' and 'student of a rural school'. Consider the theoretical results obtained.

The concept of 'information culture' has become the basis for the formation of a whole area of a complex of scientific research. Approaches to this problem were first identified in the 70s-80s in various fields of science: philosophy and science of science, computer science and semiotics, psychology and cybernetics, art history and sociology, library science and bibliography. The main trend that can be seen in the dynamics of the formation of a new research direction is associated with its multidimensionality: information culture is viewed not only as a phenomenon of the development and widespread dissemination of new electronic means of information process, but also as a kind of activity infrastructure covering all stages of human development. The spectrum of opinions regarding the definitions of the category 'information culture' is very diverse.

For example, Samokhina (2002) defines information culture as a set of stereotypes (knowledge, skills and abilities) of search, selection, ranking and presentation of information necessary for solving educational and practical problems. Andreev (1998) considers information culture as a means of forming and improving social culture.

The authors of the study are inclined to cite Krasnova (2002), who under the information culture of a person understands a subsystem of a person that ensures the proper level of the following processes of her life:

(1) Generation of mature personal meanings and, thereby, the formation of an adequate and dynamic picture of the world of the individual;

(2) Effective information exchange, ensured by the formation of a number of information skills: assessing the usefulness and truth of the information received; selection of personally significant information, search for necessary information, including the methods of its processing; communicative language skills (perception and transmission); informational and psychological selfdefence;

(3) Constant high level of information demand;

(4) Development and improvement of individually effective ways of preserving and assimilating information;

(5) Informational psychological hygiene (ecology) - self-regulation of information processes in relation to the current state of the body, and, finally;

(6) Information morality, which regulates the issues of access to other people's information, use of information for specific purposes or purposes of pressure on a person, restricting others' access to useful information.

Obviously, the content of the concept of 'information culture' can also include necessary processes and skills such as the ability to concentrate attention on an object, the ability to process information 
logically and, in value, the ability to see new combinations of properties in reflected phenomena, i.e., the ability of creative perception of information processing.

Thus, by information culture we mean a systematised set of knowledge, skills and abilities that ensure the optimal implementation of individual information activities aimed at meeting the information needs of students arising in the course of educational, scientific, cognitive and other types of activity.

In Kazakhstan, the 'rural school' occupies a special place in the education system. Thus, the share of rural schools in comparison with urban ones is approximately $47 \%$, which speaks about the territorial and geographical features of the country. The analysis of the development of rural schools in the Republic of Kazakhstan confirms that each region has its own problems and tasks in this direction. So, for example, the main problems of the functioning of small schools in Aktobe region are low provision of high-quality teaching staff, poor material and technical base, geographic remoteness, bumpy roads, adaptability of buildings, lack of gyms, subject classrooms and unused Internet resources. Difficulties in the work of small schools are also due to the lack of special textbooks and teaching aids intended for inclusive classes. The dynamics of the rural and urban population are shown in Figure 1 (http://stat.gov.kz).

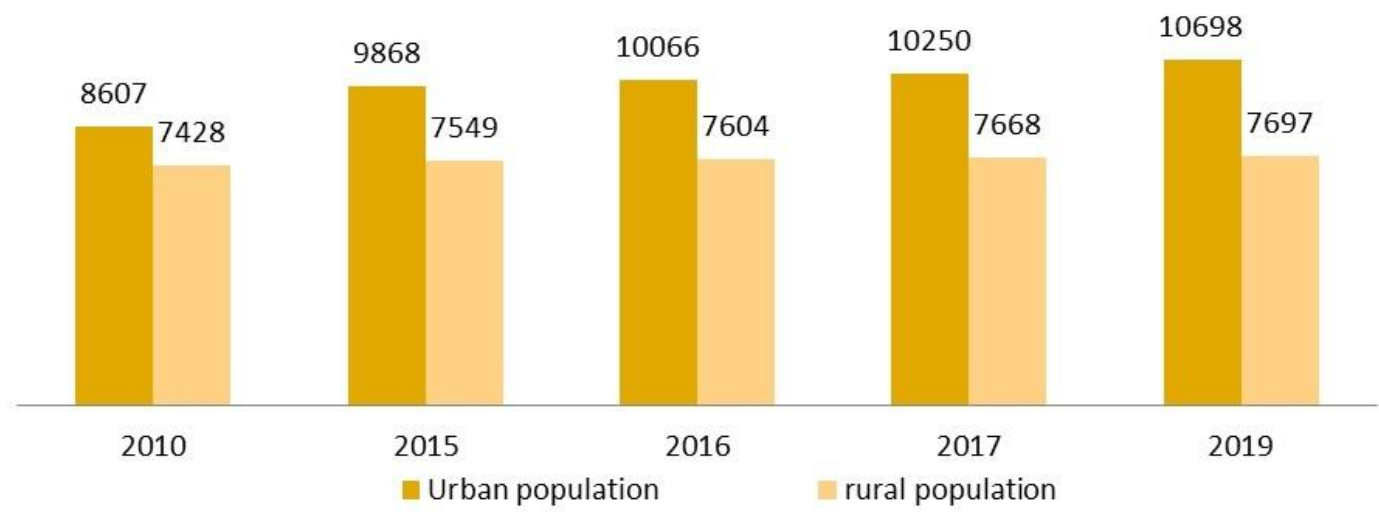

Figure 1. Rural and urban population dynamics (2010-2019)

In 2019 , the share of the rural population in Kazakhstan was $42.6 \%$ and urban was $57.4 \%$. The population growth in rural areas was $0.6 \%$ and in cities it was $1.7 \%$. The numerical data of statistical indicators indicate that the population of cities is growing twice as fast as in villages. And this is a direct indicator of the reduction of rural educational organisations. According to the data of the Strategic Plan of the Ministry of Education and Science of the Republic of Kazakhstan for 2017-2021, there is a shortage of qualified personnel, a low level of material and technical equipment should be noted: the absence of classrooms of a new modification in physics is $33.7 \%$ of schools, in chemistry is $39 \%$, biology is $39.3 \%$, mathematics is $29.3 \%$ and language laboratories is $49 \%$ (http://edu.gov.kz).

These problems require the creation of special technologies for the variable organisation and selforganisation of rural schools, the identification of effective diagnostic methods, cultural procedures and pedagogical solutions in the field of rural education.

Journalist Nurbaev (2019) in the information website 'Economist' presented five facts proving the tendency of a large gap and lagging of rural schools from urban ones in Kazakhstan, which are as follows:

(1). The gap in the material and technical base - many rural schools do not meet the regulatory requirements. An important factor influencing the results and effectiveness of the learning process at school is the level of their material and technical base. The final studies of the International 
Programme for the Assessment of Educational Achievements of Students (PISA) 2012 show the dependence of educational achievements of students on the material equipment of schools.

For the 2016-2017 academic year, 22.5\% of rural schools operated in adapted buildings. Of the 64 emergency schools, 59 were located in rural areas. According to the National Compendium 'Statistics of the Education System of the Republic of Kazakhstan 2018', in 5,293 schools (about 90\%) gyms are located in adapted buildings, $9 \%$ of rural schools do not have libraries and $8 \%$ of rural schools have canteens.

In 2005, equipping Kazakhstani schools with language laboratories, multimedia rooms and interactive whiteboards began. However, after 14 years, there is still a lack of them in rural schools. This is stated in the reports prepared by the Centre for the Development of Small Schools of the I. Altynsarin National Academy of Education. Classrooms of the new modification in physics do not have 1.102 or $33.7 \%$ of small schools, chemistry 1.273 (39\%), biology 1.283 (39.3\%), mathematics 958 (29.3\%) and language laboratories 1.600 (49\%) (https://nao.kz). At the beginning of the 2016-2017 academic year, there were no subject classrooms of a new modification in $51.5 \%$, i.e., in half of the rural schools.

(2). The provision of information and communication technologies in rural schools remains at a low level. Work is underway in Kazakhstan to develop informatisation and computerisation of education. For example, if in 2005 there was one computer for 41 students, in 2010 it was for 18 students and then in 2016 it was for 10 students.

The state supports the policy of informatisation of the education system, but serious problems still remain in this area. Kazakhstan has not yet reached acceptable global indicators of computerisation, which are five to six people per computer. Moreover, in Atyrau, Kostanay and Kyzylorda regions, not all schools are computerised. More than $35 \%$ of the total number of computers requires replacement. Only $42.3 \%$ of rural schools are equipped with interactive equipment. Only 1,075 schools are involved in the e-learning system.

(3). Rural schools lack access to broadband internet. From year to year, work is being carried out in Kazakhstani schools to increase access to the Internet. In 2015, $27.44 \%$ of the total number of schools had access to broadband internet at speeds ranging from 4 to $10 \mathrm{Mbps}$. However, a significant gap remains between individual regions: $100 \%$ access is provided in schools in Almaty, while in Aktobe and Kostanay regions this indicator is $10.66 \%$ and $13.83 \%$, respectively.

According to the results of a sociological study conducted by the author in May-August 2018, the issue of Internet access, especially broadband with a speed of more than $10 \mathrm{Mbps}$, was the most relevant. None of the small-class schools we studied had access to the Internet at a speed of more than $3 \mathrm{Mbps}$, the real speed varied from 1.5 to $2.9 \mathrm{Mbps}$. This speed does not allow, for example, keeping an electronic journal 'Kundelik', to use the electronic platform 'BilimLand'. About 95\% of the teachers surveyed answered that they were not satisfied with the speed of the Internet and that access to it was very low. In their opinion, the lack of access to broadband Internet gives rise to many problems of an educational, organisational and methodological nature.

(4). In rural schools, the qualitative characteristics of the teaching staff are comparatively low. An analysis of the qualitative composition of teachers shows a difference in the ratio of urban (92.5\%) and rural teachers $(89.3 \%)$ with higher education. Despite the fact that the majority of teachers work in rural schools, the share of rural teachers with the highest category $(16.5 \%)$ is almost two times lower than in urban schools (30.6\%). A low percentage of the teaching staff with the highest category is observed in West Kazakhstan (14.3\%), Kyzylorda (14\%) and Akmola (15.8\%) regions. The highest provision with highly qualified personnel is noted in the years: Almaty (35\%), Astana (33.7\%) and Pavlodar (31.7\%).

(5). The performance of students in rural schools is lower than in urban schools. The results of the ratings of the international and republican levels prove this thesis. Thus, according to the results of the 
International Programme for Assessment of Educational Achievements of Students PISA 2015, the results of the students of rural and urban schools are shown in Figure 2.

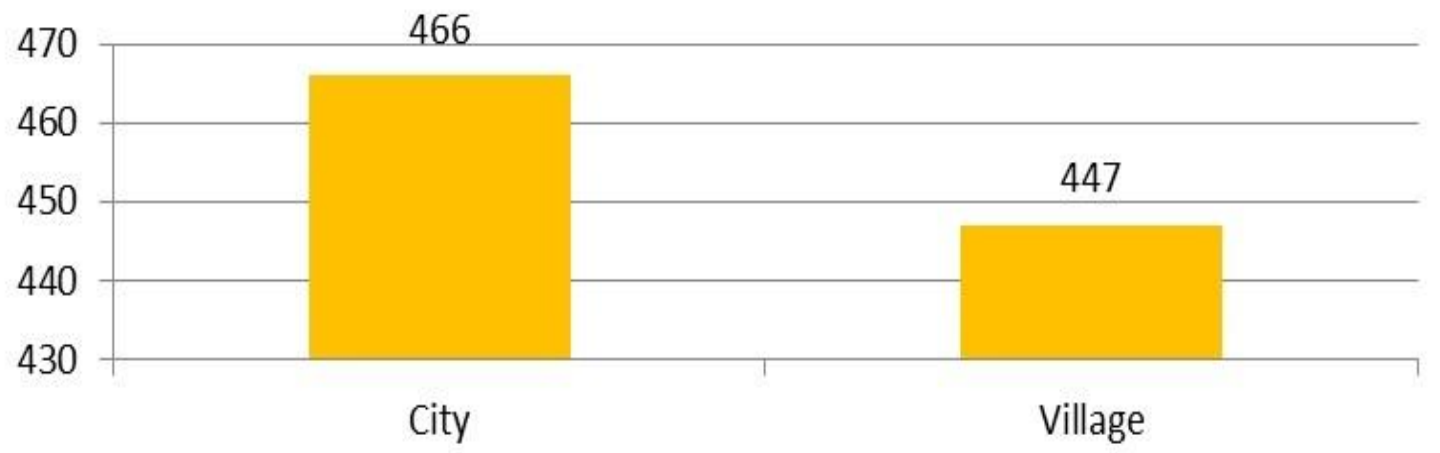

Figure 2. Results of PISA 2015 by territorial indicators

The data show a significant differentiation in the results of students in urban and rural educational organisations. The difference in PISA 2015 results of 19 points, depending on the location of the educational organisation indicates that rural schoolchildren lag behind urban peers by more than 6 months. The difference in the results of educational achievements of schoolchildren in the context of urban-rural areas is primarily due to the fact that the majority of small schools are concentrated in rural areas.

Differentiation between rural and urban schools can be traced across all basic characteristics of the educational process. The state, represented by the Ministry of Education and Science of the Republic of Kazakhstan and other bodies, are taking certain measures to reduce this gap.

In 2017, the state programme 'Digital Kazakhstan' was developed, which is aimed at providing highquality Internet in promising rural settlements. By 2025, they plan to provide more than 4,000 villages with broadband Internet. Since 2019, a joint project of the World Bank and the Ministry of Education and Science of the Republic of Kazakhstan 'Modernisation of secondary education' is being implemented. This project should equip all rural schools of the republic (about 5.4 thousand rural schools) with information and communication technology. The intersectoral project 'Auyl - El besigi' is aimed at more radical changes. Within the framework of this project, it is planned that 6.6 thousand rural settlements will be reduced and enlarged to 1.5 thousand villages. Thus, the problem with unpromising small schools will be solved. However, this can serve as a concentration in large populated areas of socially unsettled segments of the population.

One of the effective overcoming of these problems is a new system of institutions - pivotal schools (resource centres) - which provides access to quality education, the formation of the necessary key competencies in further life, as well as equal starting opportunities for school graduates for vocational training. The peculiarity of the novelty lies in the fact that three to five small remote schools are attached to the leading rural school with a high-quality teaching staff. The educational process is rebuilt according to the type of autumn, winter and spring sessions, where one-third of the academic year students spend in a pivotal school - a resource centre: they study with teachers of the highest and first category, conduct cultural events, communicate with peers, receive assignments in specially designed workers notebooks. Two-thirds of the part - in their 'magnetic' school with local teachers they solve the received tasks, communicate online and consult. Such work of the system 'resource centre - magnetic schools' in Kazakhstan is relevant and extends to all of its regions.

A network of pivotal schools - resource centres and adjoining magnetic schools - has been created in Kazakhstan. 
Table 1. Information about resource centres in the Republic of Kazakhstan

\begin{tabular}{llllll}
\hline No & Region & \multicolumn{2}{l}{$\begin{array}{l}\text { The number of functioning resource centres and adjoining magnetic schools } \\
\text { Resource centres } \\
\text { Schools }\end{array}$} & Contingent & Schools \\
& & 19 & 7,926 & 46 & Contingent \\
\hline 1 & Akmola & 11 & 3,605 & 29 & 2,952 \\
2 & Aktobe & 9 & 3,502 & 28 & 1,613 \\
3 & Almaty & 0 & 0 & 426 \\
4 & Atyrau & 0 & 3,920 & 37 & 0 \\
5 & Eastern Kazakhstan & 8 & 4,781 & 37 & 2,298 \\
6 & Zhambyl & 10 & 6,166 & 32 & 4,251 \\
7 & Western Kazakhstan & 16 & 9,577 & 183 & 2,160 \\
8 & Karaganda & 34 & 9,095 & 46 & 13,967 \\
9 & Kostanay & 17 & 0 & 0 & 3,333 \\
10 & Kyzylordinskaya & 0 & 1,315 & 5 & 0 \\
11 & Mangystau & 1 & 728 & 59 & 615 \\
12 & Pavlodar & 19 & 5,055 & 43 & 5,851 \\
13 & North Kazakhstan & 17 & 4,494 & 12 & 1,848 \\
14 & South Kazakhstan & 8 & 60,164 & 557 & 628 \\
& RK & 169 & & & 39,942 \\
\hline
\end{tabular}

Thus, the analysis of scientific, informational and analytical data on the definition of the essential characteristics of the concept of 'rural school' showed the transformation from the classical, 'nonfunctional' form of education to a modern more effective form.

Based on the definition of the concept of 'rural school', the concept of 'student of a rural school' should be disclosed. School age is important in the process of social development of a rural student the most favourable for the formation of an active personality, independent and responsible. In our opinion, the scientific and theoretical approaches highlighted by the didactic Podlasy (2012) most successfully defined the functional side of the concept of 'student of a rural school'. Let us consider them:

(1). An anthropological approach to the development of a rural school student, based on modern interdisciplinary knowledge of the essence and development of a person under the influence of an open system of educational means.

(2). Axiological approach to student development in an open information educational space. In the conditions of an open set of educational tools that contradictably affect the child, a well-thought-out system of values acts as a spiritual guide.

(3). Personality-oriented approach, which requires a fundamentally different position of the child in the organisation of activities in comparison with the traditional one: the transition from the methodology of 'personality formation' to the methodology of the child's subjective role.

(4). The ratio of innovative and traditional in the upbringing and teaching of a student in an open information educational space.

(5). Consideration of information resources and network interaction as new means of human development in the educational process.

The modern education system is called upon to form the ability to learn, navigate in the massifs of information and extract knowledge. In these conditions, the organisation of information education and the improvement of the information culture of students are of particular importance.

As part of the project, rural educational organisations of Aktobe region of the Republic of Kazakhstan were involved: Akkemer Resource Centre of the Mugalzhar region, Khromtau School 
Gymnasium No. 2 of Khromtau region and New Secondary School Lyceum in Aktobe. In total, 250 high school students and 40 teachers took part in the pedagogical research.

First, we compiled a system of components that form the information culture of a rural student (Table 2).

Table 2. The system of components that forms the information culture of a rural student

Lexical - promoting the improvement of communicative competence, its expressive means,
understanding and use of pragmatic and authentic texts; - the ability to write and convey
information;
- the ability to carry out oral communication;
- expanding the reading circle;
- assimilation and understanding the meaning of the read;
- comparison of the information received with one's own life experience;
- transferring the extracted information to others;
- expression of your attitude to what you read;
- familiarisation with sources of information;
- ability to request information;
- the ability to communicate information;
- the ability to explain information;
Intellectual $\quad$ - registration of scientific research results;
- the ability to perceive to understand the perceived information;
- the ability to explain the meaning of information;
- the ability to work in pairs and groups.

These components made it possible to determine the main methods and methodological techniques for diagnosing the initial level of information culture of schoolchildren of rural schoolchildren (Table 3).

Consider the results of diagnostic data. So, to determine the level of formation of information competence, a questionnaire was drawn up, consisting of three sections: work with sources of information; processing and presentation of information and the use of computer technology (Table 3).

Table 3. Results of diagnostics of the level of formation (final) of the communicative component

Levels Akkemer resource centre $\quad$ Khromtau school $\quad$ New secondary
(50 students) gymnasium number 2 (100 students)

\begin{tabular}{lcccccc} 
& Start & Completion & Start & Completion & Start & Completion \\
\hline High & 2 & 21 & 4 & 37 & 15 & 51 \\
Above average & 21 & 25 & 57 & 59 & 67 & 42 \\
Middle & 22 & 4 & 37 & 4 & 16 & 7 \\
Low & 5 & 0 & 2 & 0 & 2 & 0 \\
\hline
\end{tabular}

The diagnostic data indicate that the information competence in the Akkemer Resource centre was lower than that of the students of the Khromtau School Gymnasium No. 2 and the New School Lyceum. This is due to geographic and technical capabilities.

In general, the study showed a positive trend. In addition to the proven system of teaching methods, the dominance of distance learning during a pandemic are also highlighted (Figure 3). 


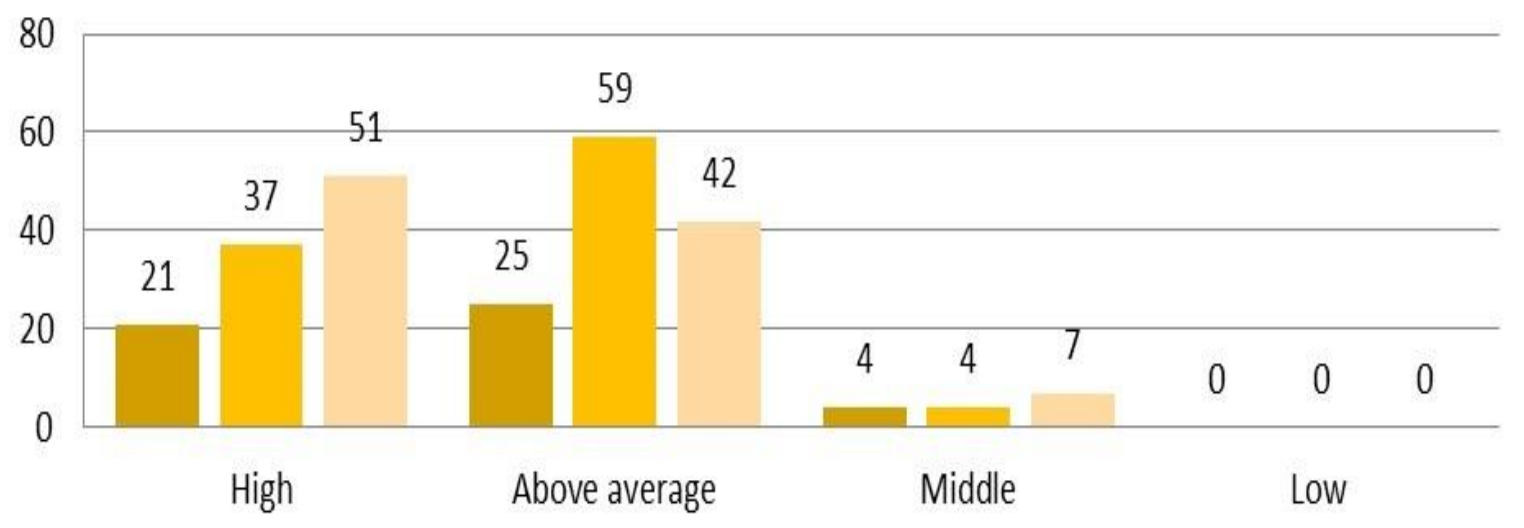

\section{Akkemer Resource Center Khromtau school-gymnasium №2 New school-lyceum}

Figure 3. Final diagnosis by definition level of information culture

Diagnostics of 50 teachers was carried out by observation as a result of interviews and questionnaires. We managed to find out the positions related to understanding the essence of information culture, the conditions for its formation and the role of using non-traditional pedagogical technologies to solve this problem (Table 4).

Table 4. Results of the questioning of teachers

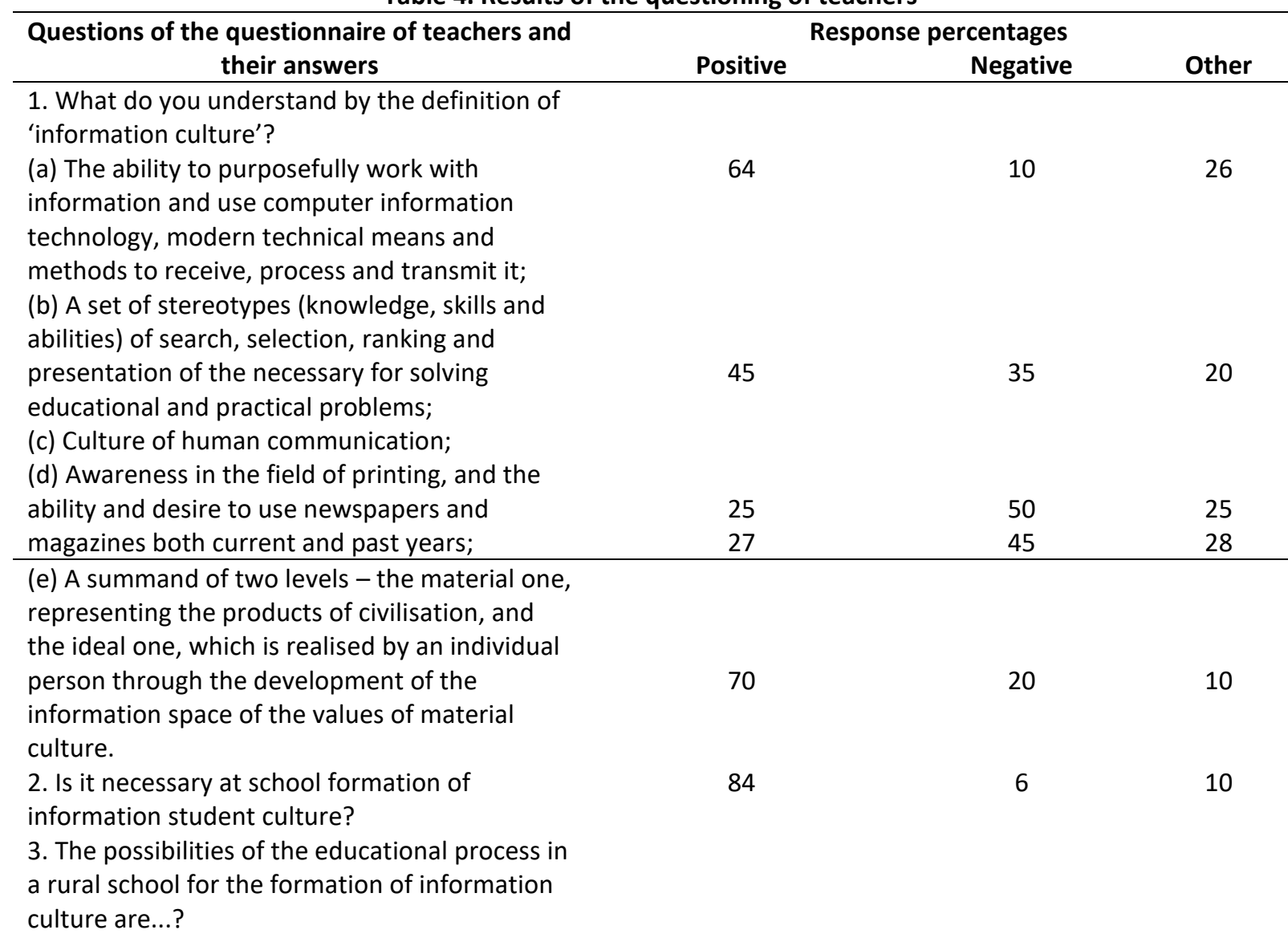


(a) Modernisation of the material and technical base of the school;

(b) Пополнение библиотечного фонда и эффективная работа школьных библиотекарей;

(c) Updating curricula, programmes, textbooks and other teaching aids;

(d) Organisation of effective work with text;

(e) Integration of educational and

extracurricular activities;

(f) Introduction of new information technologies in the educational process.

4. Do you think that non-traditional pedagogical technologies are a way to form the information culture of rural schoolchildren?

5. What types of work are used in the organisation of extracurricular activities to improve the level of information culture of schoolchildren?

(a) Information class hour;

(b) Reader's conference;

(c) Other forms.

6. Your attitude to the implementation of the pedagogical system aimed at the formation of information culture pupils.
60

An analysis of the questionnaires shows that the overwhelming majority of teachers consider it necessary to form the information culture of schoolchildren. But as for understanding the essence of 'information culture', $33 \%$ of the teachers believe that information culture is the ability to work with information, $8 \%$ of teachers believe it is awareness in the field of printing, $5 \%$ believe it is the culture of human communication and $3 \%$ believe it is a set of stereotypes of search, selection, ranking and presentation necessary for solving educational problems. Opportunities for the implementation of this process are the modernisation of the material and technical base of the school and the replenishment of the library fund.

Also, the survey data indicate that teachers use non-traditional pedagogical technologies, but do not focus on the personality-oriented interaction of the subjects of the educational process.

Thus, the analysis allows us to conclude that almost all teachers are convinced of the need to form the information culture of schoolchildren, but they do not clearly understand the conditions and principles on which the process of forming the information culture would be based. Conclusions made by us on the basis of questionnaires, observations and conversations with teachers.

To form the information culture of schoolchildren in the educational process of a rural school, we used the following forms of organising training: a lesson excursion, an information hour and a reader's conference.

Accordingly, we propose to distinguish four groups of teaching methods: visual, auditory, kinaesthetic and polymodal.

Auditory teaching methods are represented by audio information. This group includes a story, conversation, explanation and lecture. In their pure form, these methods ensure the transmission and fixation of information through the audio channel. 
Visual teaching methods involve the transfer of information in the form of an image. This is a demonstration of natural objects and visual aids, as well as work with all types of printed and written information.

Polymodal teaching methods involve the transmission of information through several channels of perception. This group should include some of the visual and all kinds of practical methods.

Audiovisual methods are designed for the simultaneous visual and auditory fixation of information during the demonstration of dia-, film and video films, some experiments and experiments.

Visual kinaesthetic methods involve the transmission of information through two channels, which increases the efficiency of its assimilation. These include the performance of graphic and written works without oral explanation, recognition and identification of natural objects, visual observations with subsequent registration of the phenomenon and work with a computer that does not have a sound card.

Audiovisual kinaesthetic methods include conducting experiments, demonstration of educational videos and films and working with computer training programmes. When using them, information is recorded across all channels.

In addition to the forms and methods of organising training, we will also consider various ways of organising educational activities aimed at forming the information culture of schoolchildren: this is work with text and non-text information, independent reading, essay, project method, student portfolio and learning in cooperation. Depending on the subject and its specifics, we selected one or another way of organising educational activities, which ensured the formation of information culture.

\section{Discussion}

Informatisation and computerisation of education determine the features of the pedagogical system, and the strategic focus on the formation of the information culture of students determines the specificity of the components of the learning process.

\subsection{Motivation}

The priorities and, as a consequence, the direction of the cognitive interest change. Obtaining a practically significant result in the process of educational activity significantly increases motivation and contributes to the formation of cognitive interest.

\subsection{Learning objectives}

The hierarchy of learning objectives is built in the context of the formation of information culture. The goals of each lesson, topic and section are aimed at the formation of its individual elements. Along with the goals of training, the goals of the development and education of personality traits necessary for a person in the information society are set.

\subsection{The content of education}

The leading content line of the course is the informational direction associated with mastering the concepts and categories of informatics, methods of information processing, communication skills and mastering the information space. It is this direction that determines the programme and thematic structure of the course. The formation of computer literacy is integrated in the process of mastering information technologies. 
Seitenova, S., Iztleuova, S., \& Imagambetova, A. (2021). Development of information culture of rural school children in the Republic of Kazakhstan. New Trends and Issues Proceedings on Humanities and Social Sciences. 8(3), pp 143-158.

https://doi.org/10.18844/prosoc.v8i3.6406

\subsection{Teaching methods}

An increase in the proportion of teaching methods that require the manifestation of activity, independence, creativity of students is due to the application of a personality-oriented approach and the organisation of joint activities of teachers and students.

\subsection{Forms of training}

The technology of organising joint activities of students provides for a sequential transition from individual educational and cognitive activities through completing tasks in pairs to group activities and training in the process of teamwork on projects.

\subsection{Control over educational and cognitive activities}

Since knowledge in any field changes rapidly, it becomes more important not to be able to store and quickly reproduce certain information, but to be able to carry out fundamentally important activities. Therefore, control is mainly in the process of carrying out an activity, by the decision process, and not by the result, i.e., feedback becomes a priority in the management of learning activities.

\section{Conclusion}

The results of the pedagogical study on the development of information culture of rural school students in Aktobe region presented in the article made it possible to draw certain conclusions. Let us consider them.

1. In Kazakhstan, more than $47 \%$ are rural schools. Recently, the Ministry of Education and Science paid special attention to the development of quality rural education in the country. For this, against the background of ordinary full-fledged rural schools, small-fledged schools and Resource Centres operate, to which magnetic small-fledged schools are attached in the adjacent territory. In total, Kazakhstan has 169 resource centres and 557 magnetic rural schools. This is due to the lack of pedagogical personnel and a scarce material and technical base.

2. As the world situation shows, the informatisation of the educational process is dominant. This gives the trainee the opportunity to receive in-depth subject training, and the teacher - the opportunity to go beyond 45 minutes of the lesson - shows professionalism, the opportunity to study outside the lesson. The parent - to independently get acquainted with the methodology of teaching a particular teacher - also gets useful psychological and educational advice.

3. The content of education at the same time should be turned into a means of forming the information culture of the individual, her abilities and talents, providing opportunities for creative selfrealisation. To this end, we have developed a pedagogical system aimed at creating an information culture of school students in a rural school, which included significant components of the educational process. For its implementation, it is necessary to observe a number of conditions (motivation of rural school students, the possibilities of humanitarian disciplines, diagnostics of the initial level of information culture of rural school students), which ensure the formation of an information culture.

4. To determine the level of formation of the information culture of school students in the process of implementing the pedagogical system, they developed a diagnostic tool that made it possible to test the effectiveness of the proposed system. Diagnosis reflects the real picture in the development of the ability to use information resources, both among students and teachers.

5. The main forms of training organisation identified by us (lesson excursion, information hour and reading conference) and groups of teaching methods (visual, audio, kinesthetic and polymodal) are 
aimed at forming the information culture of school students in the educational process of a rural school.

\section{Recommendations}

The problem of providing quality education to students in rural schools is a problem for the entire world community. The choice of forms, methods and techniques of training is determined by the educational policy of a particular state, geographical conditions, social conditions and other specific features. Presenting the peculiarities of Kazakh rural school education in this publication, we propose the following recommendations for discussion:

1. The Kazakh pedagogical community should direct professional improvement to the development of information and communication competencies. Due to the world quarantine situation, many opportunities have appeared for this: from Zoom user platforms to professional personal educational sites and other digital products.

2. A teacher of a rural school should consider all the possibilities of a student in developing his information competencies; he should fulfil the function of a tutor in the digital world and be able to properly direct himself to develop educational and personal skills.

3. In the development of information culture, the qualified and continuous work of local authorities is of great importance, playing the role of technical, information and educational opportunities of educational organisations working in its region.

4. Continuous monitoring among rural school students and their teachers will allow management bodies, methodologists and researchers to develop a promising plan for the development of information culture of rural school students.

5. Lecturers - researchers of Baishev University of Aktobe region publish the results of this study in a monograph at the republican level. This monograph can be used by scientists of other regions to study the problem of information culture development in their region of the Republic of Kazakhstan.

\section{References}

10 trendov budushchego obrazovaniya [10 trends in the future of education]. (2017). http://trends.skolkovo.ru/ 2017/10/10-trendov-budushhego-obrazovaniya/

Abylkassymova, A.E., Ryzhakov, M.V., \& Shishov, S. E. (2015). Modernizatsiya pedagogicheskogo obrazovaniya v usloviyakh innovatsionnogo razvitiya: strategicheskiye napravleniya [Modernization of teacher education in the context of innovative development: Strategic directions] (Vol., 4, pp. 7-11). Vestnik Federal'nogo gosudarstvennogo obrazovatel'nogo uchrezhdeniya vysshego professional'nogo obrazovaniya «Moskovskiy gosudarstvennyy agroinzhenernyy universitet im. V.P. Goryachkina» - Bulletin of the Federal State Educational Institution of Higher Professional Education 'Moscow State Agroengineering University. V.P. Goryachkina' [in Russian].

Adilgazinov, G. Z., \& Otcheskaya, I. B. (2005). Vyyavleniye kriteriyev intellektual'noy odarennosti cheloveka v shkolakh novogo tipa. [Identification of criteria for the intellectual giftedness of a person in a new type of schools]. Vestnik Karagandinskogo universiteta imeni Ye.A. Buketova - Bulletin of the Karaganda University named after E.A.Buketova, 4(40), 106-109 [in Russian].

Andreev, S. S. (1998). Informatsionnaya kul'tura: uroven' soderzhaniya dukhovnykh tsennostey. [Information culture: the level of content of spiritual values]. Obshchestvenno-politicheskiy zhurnal - Socio-Political Journal, 2, 79-93 [in Russian]. 
Seitenova, S., Iztleuova, S., \& Imagambetova, A. (2021). Development of information culture of rural school children in the Republic of Kazakhstan. New Trends and Issues Proceedings on Humanities and Social Sciences. 8(3), pp 143-158.

https://doi.org/10.18844/prosoc.v8i3.6406

Coursera. https://ru.coursera.org

Estonia. (2000). HITSA information technology foundation for education. https://www.hitsa.ee/aboutus/historical-overview/1997-2000

Galiev, T. T. (2011). Operezhayushcheye obucheniye na osnove sistemnogo podkhoda. Metodicheskoye posobiye. [Advance learning based on a systems approach. Study guide] ( p. 316). Publishing House of NTSOKO RK [in Russian].

Ignatova, N. Y. (2017). Obrazovaniye v epokhu tsifrovykh tekhnologiy: monografiya.[Education in the digital age: monograph] (p. 128). Ministerstvo obrazovaniya i nauki RF; FGAOU VO «UrFU imeni pervogo Prezidenta Rossii B.N. Yel'tsina». - Ministry of Education and Science of the Russian Federation; FGAOU VO "UrFU named the first President of Russia BN Yeltsin ". Nizhny Tagil: NTI (branch) UrFU [in Russian]

Karaev, J. A. (2013). Trekhmernaya metodicheskaya sistema obucheniya - osnova formirovaniya funktsional'noy gramotnosti uchashchikhsya. [Three-dimensional methodological system of teaching - the basis for the formation of functional literacy of students] (p. 11-2, 19-25). Mezhdunarodnyy zhurnal eksperimental'nogo obrazovaniya Izdatel'stvo "Akademiya yestestvennykh nauk». International Journal of Experimental Education Publishing House 'Academy of Natural Sciences' [in Russian].

KhanAcademy. https://ru.khanacademy.org

Kontaev, S. S. (2004). Innovatsionnyy obrazovatel'nyy proyekt Resursnogo tsentra. Rukovodyashchiye ukazaniya. [Innovative educational project of the Resource Center. Guidelines] (p. 58). IPK [in Russian]

Krasnova, O. V. (2002). Razvitiye informatsionnoy kul'tury lichnosti kak kompleksnaya professional'nopedagogicheskaya problema. [Development of personal information culture as a complex professional pedagogical problem] (p. 4). Mezhdunarodnyy nauchno-pedagogicheskiy Internet - zhurnal «Obrazovaniye: issledovaniya v mire». - International scientific pedagogical Internet - journal 'Education: research in the world' [in Russian].

Kusayynov, A. K., \& Bulatbaeva, A. A. (2009). Obrazovatel'naya politika: sravnitel'nyy analiz. Monografiya [Education Policy: A Comparative Analysis. Monograph] (p. 119). ROND \& A [in Russian]

Massive Open Online Courses. www.moos-ivp.org

Nurbaev, J. (2019). Sel'skiye shkoly - diskriminiruyet li gosudarstvo uchashchikhsya? [Rural schools - does the state discriminate against students?] https://ekonomist.kz/nurbayev/selskie-shkoly-diskriminiruet/ [in Russian]

Nurgalieva, G. K., Tazhigulova, A. I., \& Artykbaeva, E. V. (2015). Informatsionno-kommunikatsionnyye tekhnologii $v$ obrazovanii kak usloviye povysheniya yego kachestva. [Information and communication technologies in education as a condition for improving its quality] (pp. 22-31). Sbornik statey XVIII Mezhdunarodnoy nauchno-prakticheskoy konferentsii "Lichnost'. Obshchestvo. Obrazovaniye»: v 2-kh tomakh. "Leningradskiy - Collection of articles of the XVIII International Scientific and Practical Conference 'Personality. Society. Education': in 2 volumes. 'Leningrad Regional Institute of Education Development' [in Russian].

Podlasy, I. P. (2012). Pedagogika: uchebnik dlya bakalavrov. 2-ye izd., Pererab. I dop. [Pedagogy: a textbook for bachelors. 2nd ed., Rev. and add.] (p. 574). Yurayt Publishing House https://urait.ru/bcode/361824 [in Russian]

Respublikanskiy tsentr statisticheskikh dannykh Respubliki Kazakhstan [Republican Center for Statistical Data of the Republic of Kazakhstan]. http://stat.gov.kz [in Russian].

Samokhina, A. (2002). Formirovaniye informatsionnoy kul'tury $v$ protsesse ekonomicheskoy podgotovki starsheklassnikov [Formation of information culture in the process of economic training of high school students] (Vol. 1, pp. 27-33). Shkola Ekonomiki - School Economics [in Russian]. 
Saurambaeva, A. (2020). Trudnosti perekhoda na distantsionnoye obrazovaniye: na primere Kazakhstana [Difficulties of transition to distance education: the case of Kazakhstan]. https://cabar.asia/ru/trudnostiperehoda-na-distantsionnoe-obrazovanie-kejs-kazahstana [in Russian].

Seitaliyev, K. (2010). Stanovleniye i razvitiye psikhologicheskoy nauki v Kazakhstane. [Formation and development of Psychological Science in Kazakhstan] (pp. 5, 7-9). Psikhologiya v shkole - Psychology at School [in Russian].

Shkutin, L. A. (2002). Avtomatizirovannyye obuchayushchiye sistemy kak sostavnaya chast' sovremennykh tekhnologiy obucheniya [Automated teaching systems as a component of modern teaching technologies]. Telekommunikatsii i informatizatsiya obrazovaniya -Telecommunications and informatization of education, 5, 60-68 [in Russian].

Strategicheskiy plan Ministerstva obrazovaniya i nauki Respubliki Kazakhstan na 2017-2021 gody [Strategic plan of the Ministry of Education and Science of the Republic of Kazakhstan for 2017-2021]. http://edu.gov.kz [in Russian].

Tsentr razvitiya malykh shkol Natsional'noy akademii obrazovaniya im. I. Altynsarina Center for the Development of Small Schools of the I. Altynsarin National Academy of Education. https://nao.kz/ [in Russian]

Uzakbaeva, S. A., \& Kozhakhmetova, K. Z. (1998). Kontseptsiya etnopedagogicheskogo obrazovaniya studentov vysshey shkoly [Concept of ethnopedagogical education of students of higher education] (p. 20). Oner [in Russian]. 